\title{
Research on the Influencing Factors of Online Group- Buying Behavior Based on Unified Theory of Acceptance and Use of Technology Model
}

\author{
Mengyuan $\mathrm{Liu}^{1, *}$ \\ ${ }^{1}$ School of Business Administration, Northeastern University, Shenyang, Liaoning 10000, China \\ *Corresponding author. Email: LMY990608@163.com
}

\begin{abstract}
With the development of Internet technology, online group-buying of the emerging e-commerce model has become more and more popular with consumers. Based on the Unified Theory of Acceptance and Use of Technology (UTAUT), this paper explores the mechanism of individual perception and social influence on group-buying behavior through empirical analysis. According to the results, individual perceptions and social influences have significant positive effects on online group-buying behaviors; individual perceptions and social influences have significant positive effects on the usage intention of consumers; usage intention has a significant positive effect on the online group-buying behavior; individual perception and social influence play a part of mediating effect on the influence of online group-buying behavior. Based on this, this article puts forward corresponding marketing suggestions, with a view to providing reference for the marketing practice of online group-buying.
\end{abstract}

Keywords: online group-buying, Unified Theory of Acceptance and Use of Technology (UTAUT) model,

individual perception, social influence, usage intention

\section{INTRODUCTION}

With the rapid development of information technology, people also change the shopping mode. As a new B2T e-commerce mode, online group-buying has developed rapidly in recent years. A certain number of familiar or unfamiliar consumers organize into groups through the Internet and other channels, and purchase the same commodity on the basis of the group-buying discount lower than the retail price that can be given by the merchants, which is the so-called online groupbuying. According to the latest data of China Internet Network Information Center, as of June 2019, the number of online shopping users in China reached 639 million, with an increase of 28.71 million over the end of 2018 [1]. Taking pinduoduo, an e-commerce platform, as the example, the number of active buyers reached 483.2 million, with an increase of $41 \%$ year on year. With the rapid growth of users, the order volume of pinduoduo platform exceeded 7 billion in the first half of 2019. It can be seen that online group-buying maintains a high-speed growth under the impact of the Internet wave. However, if the online group-buying market wants to develop stably in the long term, it is necessary to study the usage intention of consumers. This has also aroused hot academic debate.
Shiau et al. [2] believe that incentive measures to save money are often used to prove the cause of online group-buying by consumers. As time goes on, more and more factors that affect consumers' participation in online group-buying have been explored. With the development of network community and competitive market environment, individual perception and other factors have become the key factors affecting consumers' willingness to participate in online groupbuying. Through the study of Chinese and foreign literature on online group-buying, $\mathrm{Li}$ Wenyong [3] found that many scholars used technology acceptance model to explore issues related to consumers' purchase intention and satisfaction. Lim et al. [4] found that perceived usefulness and perceived ease of use are significantly related to consumer attitudes, which in turn have a significant impact on the willingness to use online group buying. Li Yujie et al. [5] combined innovation diffusion theory (IDT) and technology acceptance model (TAM2), and introduced perceived price and perceived risk factor into TAM model, and found that perceived risk and perceived price had a significant impact on consumers' willingness to participate in online group-buying. It can be seen that the user experience can also promote the consumers' online group-buying. 
According to the existing literature on the influencing factors of consumers' online group-buying behavior and usage intention, most of them are devoted to the research on the constituent factors of a technology acceptance model, such as perceived usefulness, while the research on its integration is less. Based on UTAUT model, this paper introduces the user experience factor that has great impact on the consumer's usage intention into individual perception factor. Through empirical research, it explores how each factor affects the occurrence of group-buying behavior by influencing the consumer's usage intention, so as to better understand the participation intention of consumers' online group-buying, provide theoretical support and practical suggestion for business, and promote the sound development of the whole industry.

\section{THEORETICAL BASIS AND RESEARCH HYPOTHESIS}

In 2003, Venkatesh et al. [6] put forward UTAUT model, a more comprehensive model, on the basis of TAM. The results show that this model has a $70 \%$ explanatory power over intentional behavior, which is more effective than any previous model. Therefore, based on UTAUT model, this paper takes individual perception and social imfluence as independent variables, usage intention as intermediary variable, and online group-buying behavior as dependent variable to explore the mechanism of individual perception and social influence on online group-buying behavior.

\section{A. Individual perception}

The use of any new technology will make users have certain subjective perception. Corbitt [7] found that if users have a higher level of trust and experience perception in e-commerce, they will have higher willingness to participate in it. Therefore, based on the existing perceived usefulness and perceived ease of use of factor of the model, this paper introduces user experience factor into individual perception for research. Davis et al. [8] defined perceived usefulness as the extent to which people believe that the use of specific systems can improve their work performance. For example, the perceived usefulness of consumers can be measured by whether they improve their shopping efficiency. Further research by Thompson et al. [9] confirmed that the degree to which the system is understood and used will have an impact on consumers' usage intention. In addition, user experience is also an important part of individual perception. User experience was first proposed and promoted by user experience designer Donald Norman. It represents people's impression cognition and response to the products they use. [10] Fornell and other scholars pointed out that user experience is a powerful factor in predicting user quality perception, and promoting customers' quality perception has an important impact on improving the purchase possibility. According to the existing literature, individual perception is the key factor that affects the consumer experience when the consumer purchases online.

\section{B. Social influence}

Thompson et al. [9] found that when users use new technologies, their lack of experience will make the social influence more prominent, and there will have a significant impact on their usage intention. Therefore, in the follow-up study, UTAUT model introduces social influence factor on the basis of TAM, including subjective norms and social factors [11], which makes the model more explanatory. Subjective norms were first proposed by Fishbein et al. [12], who defined them as decisions made by individuals under the influence of people who have great significance to themselves. For example, if the friends around use or recommend their own use of online group-buying, consumers may have the usage intention due to the impact. Triandis [13] pointed out that social factors, i.e. the extent to which a particular social environment affects an individual's decision on whether to use new technologies, have a significant impact on human behavior. For example, in the atmosphere of shopping festival, the group-buying desire of consumers will be greatly enhanced. Therefore, this paper will divide social influence from two dimensions of subjective norms and social factors.

\section{Usage intention}

Fishbein and Ajzen put forward TRA theory in 1967, and defined the usage intention as the positive or negative feeling of the individual on the behavior of executing the target. According to the theory, human social behavior will not be affected by unconscious incentives or forces, and can be predicted by usage intention [12]. The theory of TRA is also introduced into UTAUT model, and usage intention is used as an intermediary variable to explore the influence of independent variables on the actual behavior. In recent years, usage intention is often used as an intermediary variable to explain personal use of information technology. Shiau et al. [2] found that usage intention is an intermediary variable of the influence of consumers' belief and attitude on the online group-buying application. Therefore, it is very important to study the purchase intention of consumers in the context of online group-buying.

\section{Online group-buying}

Since Groupon launched a relatively mature groupbuying transaction model in 2008, online group-buying has developed rapidly. In the opinion of Kauffman [14] and other scholars, online group buying behavior refers to the behavior of uniting customers through the Internet, improving the bargaining ability and reaching a transaction at a lower price. Li Wenyong [3] et al. 
summarized the research on online group-buying consumer behavior in China and foreign countries, and found that the current research mainly includes the following three aspects. First is mainly on exploring the impact of online group-buying. For example, Yi Liu et al. [15] found that there was herd effect in online group-buying, and consumers would observe the behavior of other group-buyers and follow the example, which reflected obvious herd mentality. Second is the study on the impact of incentive mechanism. Kauffman et al. [16] proposed sequence based incentive method, and found that the form of incentive and the limit of recommendation quantity would have a significant impact on recommendation intention. Third is the discussion on purchase intention and satisfaction. The results show that perceived price and perceived risk are both important factors influencing online group-buying behavior. Based on the above research, it is found that online group-buying has unique behavior characteristics, and exploring its influencing factors is of great significance to understand the online groupbuying behavior of consumers.

\section{E. Research hypothesis}

1) Individual perception and online group-buying behavior: The existing literature shows that a good perception process is the basis for users to accept a new technology. When having online group-buying, if consumers can have a good perception of goods, services and so on, they will tend to buy. Limayem et al. [17] have proved that perceived usefulness is one of the important factors affecting the continuous use of users, and can affect group-buying behavior through influencing attitudes. Lim et al. [4] adopted TAM, and carried out further research on it, which proved that perceived usefulness and perceived ease of use have significant relationship with consumer attitude, and consumer attitude can influence purchase behavior by influencing purchase intention. Shu [18] believes that in addition to the factors determined by UTAUT model, user experience is a significant factor influencing the use of online group-buying. Based on this, this paper proposes the following hypothesis and sub-hypothesis:

H1: individual perception affects online groupbuying behavior positively

H1a: perceived usefulness affects online groupbuying behavior positively

H1b: perceived ease affects online group-buying behavior positively

H1c: user experience has a positive impact on online group-buying behavior

2) Social influence and online group-buying behavior: According to the longitudinal study of social networking sites, Brandtzæg [19] found that when people communicate with each other, they will experience various social influences, which change their consumption concept, and then affect their behavior. The process of accepting the influence involves the subjective cognitive process of classification, recognition and comparison. It looks for similar people as a reference, so as to try and use new technology. Saks et al. [20] confirmed the importance of subjective norms in subsequent studies, which significantly affected the purchase behavior. In addition, many follow-up studies show that there are many factors that will change consumer behavior under the influence of society, such as social factors. Lee et al. [21] studied social factors as a structure reflecting the influence of society on behavior, and the results showed that social factors have been proved to have significant and lasting influence on voluntary behavior. Therefore, this paper proposes the following hypothesis and sub-hypothesis:

$\mathrm{H} 2$ : social impact has a positive impact on online group-buying behavior

H2a: subjective norms have a positive impact on online group-buying behavior

$\mathrm{H} 2 \mathrm{~b}$ : social factors affect online group-buying behavior positively

3) Individual perception and online group-buying usage intention: Many studies have shown that individual perception has a significant role in promoting online group-buying usage intention. Ajzen's attitude theory holds that human behavior is influenced by subjective perception, even if it is biased or inaccurate. Based on Davis' research, Adams et al. [23] proved that perceived usefulness and perceived ease of use can promote the usage intention. Bhattacherjee [24] confirmed that consumers' intention is determined by the interaction among their satisfaction with initial service, perceived ease of use, perceived usefulness and loyalty incentive of service use. When improving Model of PC utilization, Thompson et al. [25] found that when individuals feel happy because of a certain behavior, they will have a strong willingness to use the information technology. Therefore, this paper proposes the following hypothesis and sub-hypothesis:

$\mathrm{H} 3$ : individual perception has a positive impact on online group-buying usage intention

$\mathrm{H} 3 \mathrm{a}$ : perceived usefulness has a positive impact on online group-buying usage intention

$\mathrm{H} 3 \mathrm{~b}$ : perceived ease of use has a positive impact on online group-buying usage intention 
H3c: user experience has a positive impact on online group-buying usage intention

4) Social influence and online group-buying usage intention: Social influence will affect online groupbuying usage intention, which is consistent with the research results of Kim et al. [26]. In TRA theory, attitude and subjective norms are the decisive factors of behavior intention. According to further studies, Mun et al. [27] have proved that subjective norms and perceptual behavior control have significant effects on behavioral intention. In addition, Lee et al. [28] have found that social factor is another important factor influencing users' willingness to purchase online, in addition to personal factors. Also, it has proved that experience effect plays a regulatory role between social factors and usage intention. Based on the above research, this paper proposes the following hypotheses and sub-hypotheses:

H4: social impact has a positive impact on online group-buying usage intention

H4a: subjective norms have a positive impact on online group-buying usage intention

H4b: social factors have a positive impact on online group-buying usage intention

5) Usage intention and online group-buying behavior: Relevant research shows that when consumers have strong expectations and strong usage intention, online group-buying behavior is more likely to occur. Venkatesh et al. [11] have studied that continuous use may not be the result of careful consideration, but just the routine or automatic response to stimulation. In the following research, it is pointed out that the intention of behavior and promotion conditions are very important when predicting the use behavior of consumers. Fishbein et al. [29] conducted further research, and the results showed that intention and perceived behavior control could be used to predict subsequent behavior, confirming that purchase intention is related to actual behavior. Based on this, this paper proposes the following hypothesis:

H5: usage intention affects online group-buying behavior positively

\section{$F$. Intermediary role of usage intention}

The relaxed and pleasant purchase process can make consumers have a good perception experience, which has a significant impact on promoting purchase behavior. Yang et al. [30] believe that the key to improving the competitive advantage of enterprises is to improve the individual perception and satisfaction of consumers, and then to promote the purchase behavior by improving the usage intention. In addition, social influence will also change consumers' usage intention. The greater the influence is, the more likely it is to deepen the usage intention, resulting in purchase behavior. Qin et al. [31] focused on the research of social impact on online social network users' acceptance, proving that it affects consumer behavior by influencing their usage intention. Based on the above research, this paper proposes the following hypotheses and sub-hypotheses:

H6: usage intention plays an intermediary role in the relationship between individual perception, social influence and online group-buying behavior

H6a: individual perception influences online groupbuying behavior through usage intention

H6b: social influence affects online group-buying behavior through usage intention

Based on the above assumptions, the theoretical model of this study is shown in "Fig. 1".

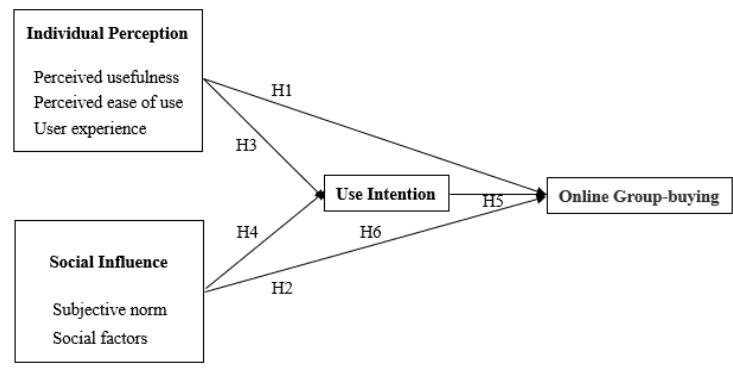

Fig. 1. Theoretical model of this study.

\section{RESEARCH HYPOTHESIS}

\section{A. Variable design}

Based on the previous discussion and model, this study designs a questionnaire, which consists of two parts. The first part is the basic information, which is mainly used to measure the control variables of the study, including gender, age, education background, monthly living expenses, etc. The second part is the main part, which is mainly used to measure the independent variables, intermediate variables and dependent variables. The measurement of individual perception and social influence is based on the scale of Davis [8] and Venkatesh [6] and other scholars. The usage intention is adapted from the scale of Venkatesh [6] and Li Yujie [5]. The measurement of online groupbuying behavior is based on the scale of Moon [32] and other scholars. The questionnaire is measured with Likert five-point scale. From 1 to 5 , it means the degree from very disagree to very agree. Spss22.0 software is performed to analyze the data. 


\section{B. Data collection and descriptive statistics of sample data}

The subjects of this study are consumers who have used online group-buying for shopping. The authors sent questionnaires through the Internet and collect data for analysis. A total of 370 questionnaires were issued, 358 of which were effectively recovered, with a recovery rate of $96.76 \%$. After deleting the abnormal values, 336 of them were effective, with a sample efficiency of $93.85 \%$, meeting the requirement that the effective sample size was 5 times of the measurement items. In order to understand the structural characteristics of the sample more clearly, this paper makes descriptive statistics for the basic information of the sample (as shown in "Table I"). Compared with men, women are more interested in online shopping, and they are more likely to use online group-buying. Therefore, $56.25 \%$ of women in this study are in line with the reality. The age distribution of this sample is dominated by young people under 30 years old, which is consistent with the statistical status of China Internet Network Information Center.

TABLE I. BASIC INFORMATION STATISTICS OF SURVEY SAMPLE

\begin{tabular}{|l|l|l|l|}
\hline \multicolumn{1}{|c|}{ Name } & \multicolumn{1}{|c|}{ Category } & Sample number & Percentage \\
\hline \multirow{4}{*}{ Gender } & Male & 147 & $43.75 \%$ \\
\cline { 2 - 4 } & Female & 189 & $56.25 \%$ \\
\hline \multirow{4}{*}{ Age } & 20 years old and below & 114 & $33.93 \%$ \\
\cline { 2 - 4 } & $21-30$ & 197 & $58.63 \%$ \\
\cline { 2 - 4 } & $31-40$ & 15 & $4.46 \%$ \\
\cline { 2 - 4 } & 41 years old and above & 10 & $2.98 \%$ \\
\hline \multirow{4}{*}{ Education background } & Senior high school & 57 & $16.96 \%$ \\
\cline { 2 - 4 } & Junior college & 91 & $27.08 \%$ \\
\cline { 2 - 4 } & Bachelor & 187 & $55.65 \%$ \\
\cline { 2 - 4 } & Master or above & 1 & $0.3 \%$ \\
\hline \multirow{4}{*}{ Cost of living (month) } & Less than 1000 yuan & 48 & $31.29 \%$ \\
\cline { 2 - 4 } & $1000-2000$ yuan & 107 & $9.52 \%$ \\
\cline { 2 - 4 } & $2000-3000$ yuan & 32 & $44.35 \%$ \\
\cline { 2 - 4 } & More than 3000 yuan & 149 & \\
\hline
\end{tabular}

\section{Data ANALYSIS}

\section{A. Reliability, validity test and factor analysis}

In order to ensure the validity of the questionnaire, this study makes the reliability and validity test and factor analysis of the sample data, so as to check the rationality of the item content. In the reliability analysis, Cronbach's $\alpha$ coefficient is used to test the reliability of the items. It is found that the overall Cronbach's $\alpha$ value of the questionnaire is 0.968 , and the Cronbach's $\alpha$ value of all variables is greater than 0.7 , proving that the scale has high consistency, can measure the research objectives stably, and pass the reliability test. In the validity analysis, KMO test and Bartlett spherical test are used. It is found that the KMO value of each variable is greater than 0.7 , and the structural validity is good. The approximate chi-square value of Bartlett spherical test is 4957.385 , the degree of freedom is 171 , and the sig value is 0.000 , reaching a significant level. Therefore, it is suitable for factor analysis. It can be seen from "Table II" that the factor loading value of each item is greater than 0.8, indicating that the scale is set reasonably and the overall validity is good.

TABLE II. RESULTS OF RELIABILITY AND VALIDITY ANALYSIS

\begin{tabular}{|c|c|c|c|c|c|c|c|c|}
\hline \multirow{2}{*}{\multicolumn{2}{|c|}{ Variable name }} & \multirow{2}{*}{$\begin{array}{c}\text { Measuring } \\
\text { project }\end{array}$} & \multirow{2}{*}{$\begin{array}{c}\text { Cronbach's } \\
\alpha \\
\end{array}$} & \multirow{2}{*}{ KMO } & \multicolumn{3}{|c|}{ Bartlett's Test } & \multirow{2}{*}{$\begin{array}{l}\text { Factor } \\
\text { loading }\end{array}$} \\
\hline & & & & & The approximate chi-square & $\mathrm{DF}$ & Sig. & \\
\hline \multirow{8}{*}{$\begin{array}{l}\text { Individual } \\
\text { perception }\end{array}$} & \multirow{2}{*}{$\begin{array}{l}\text { Perceived } \\
\text { Usefulness }\end{array}$} & PU1 & \multirow{8}{*}{.931} & \multirow{8}{*}{.946} & \multirow{8}{*}{1787.457} & \multirow{8}{*}{36} & \multirow{8}{*}{.000} & .831 \\
\hline & & PU2 & & & & & & .814 \\
\hline & Perceived & PEOU1 & & & & & & .821 \\
\hline & Ease of use & PEOU2 & & & & & & .832 \\
\hline & \multirow{4}{*}{$\begin{array}{l}\text { UE(user } \\
\text { experience) }\end{array}$} & UE1 & & & & & & .803 \\
\hline & & UE2 & & & & & & .813 \\
\hline & & UE3 & & & & & & .824 \\
\hline & & UE4 & & & & & & .835 \\
\hline \multirow{3}{*}{$\begin{array}{l}\text { social } \\
\text { influence }\end{array}$} & subjective & SN1 & \multirow{3}{*}{.872} & \multirow{3}{*}{.832} & \multirow{3}{*}{649.089} & \multirow{3}{*}{10} & \multirow{3}{*}{.000} & .876 \\
\hline & norm & SN2 & & & & & & .845 \\
\hline & social & SF1 & & & & & & .842 \\
\hline
\end{tabular}




\begin{tabular}{|c|c|c|c|c|c|c|c|}
\hline influence & SF2 & & & & & & .836 \\
\hline \multirow{2}{*}{ Variable name } & \multirow{2}{*}{$\begin{array}{c}\text { Measuring } \\
\text { project }\end{array}$} & \multirow{2}{*}{$\begin{array}{c}\text { Cronbach's } \\
\alpha\end{array}$} & \multirow{2}{*}{ KMO } & \multicolumn{3}{|c|}{ Bartlett's Test } & \multirow{2}{*}{$\begin{array}{r}\text { Factor } \\
\text { loading }\end{array}$} \\
\hline & & & & The approximate chi-square & $\mathrm{DF}$ & Sig. & \\
\hline \multirow{3}{*}{ usage intention } & UI1 & \multirow{3}{*}{.816} & \multirow{3}{*}{.718} & \multirow{3}{*}{346.175} & \multirow{3}{*}{6} & \multirow{3}{*}{.000} & .846 \\
\hline & UI2 & & & & & & .853 \\
\hline & UI3 & & & & & & .863 \\
\hline \multirow{3}{*}{$\begin{array}{l}\text { Online } \\
\text { behavior }\end{array}$} & OG1 & \multirow{3}{*}{.841} & \multirow{3}{*}{.728} & \multirow{3}{*}{405.394} & \multirow{3}{*}{6} & \multirow{3}{*}{.000} & .879 \\
\hline & OG2 & & & & & & .871 \\
\hline & OG3 & & & & & & .861 \\
\hline
\end{tabular}

\section{B. Correlation analysis}

In the correlation analysis of variables, Pearson correlation analysis is used in this study. According to "Table III", individual perception and social influence are positively correlated with usage intention and online group-buying behavior. And usage intention is positively correlated with online group-buying behavior. The confidence interval is 0.01 , which is consistent with the expected hypothesis. The next step of regression analysis can be carried out.

TABLE III. CORRELATION COEFFICIENT AMONG VARIABLES

\begin{tabular}{|c|c|c|c|c|c|c|c|c|}
\hline & Gender & Age & $\begin{array}{c}\text { Education } \\
\text { background }\end{array}$ & $\begin{array}{l}\text { Cost of } \\
\text { living } \\
\text { (month) }\end{array}$ & $\begin{array}{l}\text { Individual } \\
\text { perception }\end{array}$ & $\begin{array}{c}\text { Social } \\
\text { influence }\end{array}$ & $\begin{array}{c}\text { Usage } \\
\text { intention }\end{array}$ & $\begin{array}{l}\text { Online } \\
\text { group- } \\
\text { buying } \\
\text { behavior }\end{array}$ \\
\hline Gender & 1 & & & & & & & \\
\hline Age & $.156^{* *}$ & 1 & & & & & & \\
\hline Education background & -.018 & $.384^{* *}$ & 1 & & & & & \\
\hline Cost of living (month) & $.112^{*}$ & $.561^{* *}$ & $.338^{* *}$ & 1 & & & & \\
\hline Individual perception & -.081 & .055 & $.338^{* *}$ & $.165^{* *}$ & 1 & & & \\
\hline Social influence & -.102 & .075 & $.332^{* *}$ & $.147^{* *}$ & $.920^{* *}$ & 1 & & \\
\hline Usage intention & -.106 & .047 & $.288^{* *}$ & $.156^{* *}$ & $.870^{* * *}$ & $.857^{* *}$ & 1 & \\
\hline $\begin{array}{l}\text { Online group-buying } \\
\text { behavior }\end{array}$ & $-.135^{*}$ & .024 & $.336^{* *}$ & $.145^{* *}$ & $.884^{* *}$ & $.870^{* *}$ & $.836^{* *}$ & 1 \\
\hline Average deviation & 1.56 & 1.76 & 2.39 & 2.84 & 3.73 & 3.73 & 3.72 & 3.72 \\
\hline Standard deviation & 0.497 & 0.670 & 0.765 & 1.145 & 1.038 & 1.067 & 1.053 & 1.092 \\
\hline
\end{tabular}

\section{Regression analysis}

1) Regression analysis of individual perception, social influence and online group-buying behavior: In order to explore the direct impact of online groupbuying behavior, this study uses regression analysis. The individual perception and social influence are taken as independent variables, and the online group-buying behavior is taken as dependent variables. According to the standard coefficient in "Table IV", individual perception, social influence and online group-buying behavior all have significant positive effects. The standardized coefficient is 0.528 and 0.364 respectively, that is, $\mathrm{H} 1$ and $\mathrm{H} 2$ are true.

2) Regression analysis of individual perception, social influence and usage intention: In the process of research on the influence of usage intention, individual perception and social influence are taken as independent variables, and usage intention is taken as dependent variable. The regression results show that individual perception and social influence have significant positive effects on the usage intention. The standardized coefficients are 0.531 and 0.368 , respectively. $\mathrm{H} 3$ and $\mathrm{H} 4$ are established, individual perception is the most likely to cause the usage intention of online group-buying.

3) Regression analysis of usage intention and online group-buying behavior: The correlation coefficient between usage intention and online groupbuying behavior is 0.796 , showing a significant positive correlation, and proving that $\mathrm{H} 5$ is true. The usage intention and online group-buying behavior have a significant positive influence.

4) An analysis on the intermediary effect of usage intention: In the above three-step test, the measurement variables have significant positive effects. In the analysis of intermediary variables, the results show that the promotion of individual perception and social influence on online group-buying behavior has been weakened, while the usage intention still has a significant positive impact on online group-buying behavior, indicating that the usage intention plays a part of intermediary role in individual perception, social influence and online group-buying behavior, i.e. H6 is valid. 
TABLE IV. REGRESSION ANALYSIS RESULTS

\begin{tabular}{|l|l|l|l|l|}
\hline \multicolumn{1}{|c|}{ Variable } & Usage intention & \multicolumn{1}{|c|}{$\begin{array}{c}\text { Online group-buying } \\
\text { behavior }\end{array}$} & $\begin{array}{c}\text { Online group- } \\
\text { buying behavior }\end{array}$ & $\begin{array}{c}\text { Online group-buying } \\
\text { behavior }\end{array}$ \\
\hline Control variable & & \multicolumn{1}{c|}{} & \\
\hline Gender & -.027 & -.048 & -.049 & -.042 \\
\hline Age & -.016 & -.059 & -.067 & -.055 \\
\hline Education background & -.019 & .049 & .124 & .053 \\
\hline Cost of living (month) & .032 & .026 & .022 & .020 \\
\hline Independent variable & & & & \\
\hline Individual perception & $.531^{* *}$ & $.528^{* *}$ & - & $.421^{* *}$ \\
\hline Social influence & $.368^{* *}$ & $.364^{* *}$ & - & $.289^{* *}$ \\
\hline Intervening variable & & & & \\
\hline Usage intention & - & - & $.796^{* *}$ & $.202^{* *}$ \\
\hline R2 & .780 & .809 & .714 & .710 \\
\hline Adjusted r2 & .766 & .805 & $165.038^{* *}$ & .818 \\
\hline F & $194.307^{* *}$ & $231.654^{* *}$ & $209.987^{* *}$ \\
\hline
\end{tabular}

\section{CONCLUSIONS AND SUGGESTIONS}

\section{A. Research conclusions}

Based on UTAUT model, this paper puts forward a research model that affects the online group-buying behavior of consumers, and tests the hypothesis through empirical analysis. The main conclusions are as follows:

1) Individual perception and social influence have significant positive effects on online group-buying behavior: In the process of exploring the influence mechanism of independent variables on online groupbuying behavior, it finds that individual perception and social influence have significant influence on online group-buying behavior. Among them, individual perception has the most significant effect on online group-buying behavior. With the development of Internet technology, the form of technological innovation is changing, and More and more attention has been paid to the user-centered idea. Therefore, good individual perception will increase the consumer's favorability, and then promote the online group-buying behavior. In addition, social influence is an important factor in promoting the adoption of group-buying technology by consumers. People are not isolated individuals in the real society. As members of the society, all kinds of social conditions will directly or indirectly affect people, changing everyone's thinking and action. For example, when the friends around make the decision of online group-buying, the individual's own purchase decision-making behavior will also be affected, and they tend to make the decision-making of group-buying.

2) Individual perception, social influence and usage intention have significant positive effects: From the above data analysis, it can see that individual perception and social influence have a significant impact on the online group-buying usage intention. When the technical conditions are similar, consumers pay more attention to the sense of experience whether it is virtual service or physical service. Therefore, in the process of online group-buying, the pleasant, safe and convenient perception experience can effectively promote consumers' purchase desire and stimulate consumers' usage intention. The influence of social influence factors on consumers' usage intention is multifaceted. Driven by social factors such as shopping festivals, consumers' usage intention will increase with the change of atmosphere; and sometimes just the words or behaviors of others can make consumers themselves affected.

3) Usage intention has a significant positive impact on online group-buying behavior: Behavior can't be produced without the individual's subjective will. With the influence of various social factors, consumers' perceived usefulness, perceived ease of use and other experiences improve consumers' perception expectations, and consumers will have a strong usage intention, and have online group-buying behavior.

4) Usage intention has partial mediating effect: The results show that usage intention plays a part of mediating role in individual perception, social influence and online group-buying behavior. As an intermediary variable, usage intention can enhance the positive role of individual perception and social influence, and then promote online group-buying behavior. According to data analysis, it shows that individual perception is the most important factor that affects the online groupbuying behavior of consumers. A good perception experience not only has a direct impact on the online group-buying behavior of consumers, but also has an indirect impact by improving the individual's usage 
intention. The influence of usage intention on social influence factor is similar and will not be discussed.

\section{B. Marketing suggestions}

1) Focusing on improving user perception and promoting sticky consumption: First of all, online group-buying activities can make consumers get more affordable prices, stimulate the desire to buy, and facilitate the actual purchase behavior. Secondly, businesses have formed good word-of-mouth communication while obtaining benefits and returns. For both sides, online group-buying is a win-win way, so this business model is more and more popular. According to the previous analysis, individual perception has the most significant impact on online group-buying behavior. Therefore, when designing websites, businesses should focus on the optimization from the perspective of individual perception, so as to enhance consumers' sense of experience. Therefore, the sense of dependence can be enhanced and the sticky consumption can be promoted.

In the Internet era, there is no obvious difference between the quality and function of products. Consumers tend to choose products based on experience, so obtaining pleasure is the premise of consumers' purchase. For the promotion of pleasure, businesses should first pay attention to the design of website interface. Excellent visual design will give users a good audio-visual experience, thus laying the foundation for a long-term pleasant experience. Secondly, businesses can prepare some small surprises, such as giving a mysterious small gift at random after purchase, which can effectively add fun and enhance the purchase desire of consumers. In addition, businesses should also pay attention to the risk of consumers in the purchase process, and reduce the perceived risk through different ways. For example, when customers are not sure whether to buy or not, it is necessary to provide expert certification to make customers believe that the product performance is excellent, or to provide free samples to give customers the opportunity to try new products before buying.

2) Comprehensively improving social influence and stimulating purchase desire: With the development and progress of society, social influence plays a crucial role in people's decision-making. According to the previous text, it has also proved that social influence has a significant impact on online group-buying usage intention. Therefore, marketers should make full use of consumers' consumption psychology which will be affected by colleagues, friends and other social influences, and improve social influence from different perspectives. For example, in the Double Eleven, Double Twelve and other large-scale shopping festivals, businesses can launch a variety of different preferential group-buying programs to attract the public's attention. Under the influence of the shopping festival, consumers' purchase desire will be greatly enhanced. Secondly, in the usual publicity, it is required to invite famous stars to be the represent, and improve the social influence of the brand. Consumers who are fans are more likely to form groups to buy.

3) Being dedicated to guiding consumers to have usage intention: People's social behavior will not come into being for no reason. Through some influences, it promotes consumers' usage intention and the occurrence of purchase behavior. Therefore, businesses should pay more attention to the role of usage intention in the process of producing purchase behavior and guide consumers to have usage intention. In the sales process, it is necessary to pay special attention to the feedback of consumers, especially the negative information, and contact the buyer in time to do a good job of after-sales service, so as to create a high-quality online reputation, so that consumers are more likely to have online group-buying willingness.

\section{References}

[1] China Internet Network Information Center. The 44th Statistical Report on Internet Development in China [R]. 2019.

[2] Shiau, Wen-Lung, and Margaret Meiling Luo. Factors affecting online group buying intention and satisfaction: A social exchange theory perspective[J].Computers in Human Behavior 28.6 (2012): 2431-2444.

[3] Li Wenyong, Wang Su, Cheng Junjie. Review and Prospect of Online Group- buying Behaviour in China and foreign countries [J]. Commercial Economics Research, 2016 (06): 79-81. (in Chinese)

[4] Lim, Weng Marc, and Ding Hooi Ting.Consumer acceptance and continuance of online group buying[J]. Journal of Computer Information Systems 54. 3 (2014): 87-96.

[5] Li Yujie, Liao Chenglin. Personal Perception, Innovation Diffusion and Consumer Participating in Online Group- buying Behaviour [J]. Commercial Research, 2013 (11): 45-53. (in Chinese)

[6] Venkatesh, V., Morris, M. G., Davis, G. B., \& Davis, F. D.User acceptance of information technology: Toward a unified view[J].MIS quarterly (2003): 425-478.

[7] Corbitt, Brian J., Theerasak Thanasankit, and Han Yi. Trust and e-commerce: a study of consumer perceptions[J]. Electronic commerce research and applications 2.3 (2003): 203-215.

[8] Davis, F. D. Perceived usefulness, perceived ease of use, and user acceptance of information technology[J] . MIS Quarterly, 1989, (13) : 319-340.

[9] Thompson, R. L., Higgins, C. A., and Howell, J. M. Influence of Experience on Personal Computer Utilization: Testing a Conceptual Model [J]. Journal of Management Information Systems (11:1), 1994, pp. 167-187.

[10] Fornell, Claes, et al. The American customer satisfaction index: nature, purpose, and findings[J]. Journal of marketing 60.4 (1996): 7-18 
[11] Venkatesh, V., \& Davis, F. D. (2000). A theoretical extension of the technology acceptance model: Four longitudinal field studies[J]. Management science, 46(2), 186-204.

[12] Fishbein, M., and Ajzen, I. Belief, Attitude, Intention and Behavior: An Introduction to Theory and Research[J]. Addison-Wesley, Reading, MA, 1975.

[13] Triandis, H. C. Interpersonal Behavior[J]. Brooke/ Cole, Monterey, CA, 1977.

[14] Kauffman, Robert J., and Bin Wang. Bid together, buy together: On the efficacy of group-buying business models in Internetbased selling[J].The e-business handbook (2002): 99-137.

[15] Liu, Yi, and Juliana Sutanto. Buyers' purchasing time and herd behavior on deal-of-the-day group-buying websites[J]. Electronic Markets 22.2 (2012): 83-93.

[16] Kauffman, Robert J., Hsiangchu Lai, and Chao-Tsung Ho. Incentive mechanisms, fairness and participation in online group-buying auctions[J]. Electronic Commerce Research and Applications 9.3 (2010): 249-262.

[17] Limayem, Moez, Sabine Gabriele Hirt, and Christy MK Cheung. How habit limits the predictive power of intention: The case of information systems continuance[J]. MIS quarterly (2007): 705-737.

[18] Shu, Wesley. Why do people make online group purchases? Risk avoidance, sociability, conformity, and perceived playfulness[J]. Management Information Systems Review 17.1 (2011): 63-88.

[19] Brandtzæg, Petter Bae. Social networking sites: Their users and social implications-A longitudinal study[J]. Journal of Computer-Mediated Communication 17.4 (2012): 467-488.

[20] Saks, Alan M., and Blake E. Ashforth. Organizational socialization: Making sense of the past and present as a prologue for the future[J]. Journal of vocational Behavior 51.2 (1997): 234-279.

[21] Lee, Younghwa, Jintae Lee, and Zoonky Lee. Social influence on technology acceptance behavior: self-identity theory perspective[J]. ACM SIGMIS Database: the DATABASE for Advances in Information Systems 37.2-3 (2006): 60-75

[22] Ajzen, Icek. The theory of planned behavior[J]. Organizational behavior and human decision processes 50.2 (1991): 179-211.

[23] Adams, Dennis A., R. Ryan Nelson, and Peter A. Todd. Perceived usefulness, ease of use, and usage of information technology: A replication[J]. MIS quarterly (1992): 227-247.

[24] Bhattacherjee, Anol. An empirical analysis of the antecedents of electronic commerce service continuance[J]. Decision support systems 32.2 (2001): 201-214.

[25] Thompson, R. L., Higgins, C. A., and Howell, J. M. Personal Computing: Toward a Conceptual Model of Utilization[J].MIS Quarterly (15:1), 1991, pp. 124-143.

[26] Kim, Hong-bumm, Taegoo Terry Kim, and Sung Won Shin. Modeling roles of subjective norms and eTrust in customers' acceptance of airline B2C eCommerce websites[J]. Tourism management 30.2 (2009): 266-277.

[27] Mun, Y. Yi, et al. Understanding information technology acceptance by individual professionals: Toward an integrative view[J]. Information \& Management 43.3 (2006): 350-363.

[28] Lee, Hae Young, Hailin Qu, and Yoo Shin Kim. A study of the impact of personal innovativeness on online travel shopping behavior-A case study of Korean travelers[J]. Tourism Management 28.3 (2007): 886-897.

[29] Fishbein, Martin, and Icek Ajzen. Understanding attitudes and predicting social behavior[J]. (1980).

[30] Yang, Zhilin, and Robin T. Peterson. Customer perceived value, satisfaction, and loyalty: The role of switching costs[J]. Psychology \& Marketing 21.10 (2004): 799-822.
[31] Qin, Li, et al. The effects of social influence on user acceptance of online social networks[J]. International Journal of HumanComputer Interaction 27.9 (2011): 885-899.

[32] Moon, Ji-Won, and Young-Gul Kim. Extending the TAM for a World-Wide-Web context[J]. Information \& management 38.4 (2001): 217-230. 